UDC 061.2(477:437):94(100)“1939/1941"

DOI: 10.24919/2519-058x.17.219463

\title{
Oksana SALATA
}

PhD hab. (History), Professor, Head of the Department of History of Ukraine Borys Hrinchenko Kyiv University, 18/2 Boulevard-Kudryavskaya Street, Kyiv, Ukraine, postal code04053 (o.salata@kubg.edu.ua)

ORCID: 0000-0003-2498-1483

ResearcherID: 3110770

\section{Оксана САЛАТА}

доктор історичних наук, професор, завідувач кафедри історії Украӥни Київського університету імені Бориса Грінченка, вул. Бульварно-Кудрявська, 18/2, м. Київ, Україна, індекс04053 (o.salata@kubg.edu.ua)

Bibliographic Description of the Article: Salata, O. (2020). Activities of the Ukrainian Historical and Philological Society in Prague during initial period of World War II(1939-1941). Skhidnoievropeiskyi Istorychnyi Visnyk [East European Historical Bulletin], 17. 175-183. doi: 10.24919/2519-058x.17.219463

\section{ACTIVITIES OF THE UKRAINIAN HISTORICAL AND PHILOLOGICAL SOCIETY IN PRAGUE DURING INITIAL PERIOD OF WORLD WAR II (1939 - 1941)}

\begin{abstract}
The purpose of the research - to reveal the activities of the Ukrainian Historical and Philological Society in Prague under the difficult conditions of the outbreak of World War II, especially its activity, publishing of scientific works and maintaining relations with scientific centers of Czechoslovakia. The research methodology is based on the general scientific (analysis, synthesis, generalization) and special historical (historical typological, historical comparative) methods, the principles of historicism, systematic, scientific, verification of the author's objectivity. By applying the historical typological method, the author was more likely to disclose the goals and objectives of the study. The scientific novelty is that for the first time in the Ukrainian and foreign historiography the activity of the Ukrainian Historical and Philological Society in Prague has been elucidated under conditions of the beginning of World War II, in particular, the publishing activity of the Society in difficult political and financial conditions. The Conclusions. Despite the difficult political and economic conditions in Czechoslovakia at the beginning of World War II, the Ukrainian Historical and Philological Society in Prague continued its activity. At the meetings of the Society there was discussed a variety of issues concerning history and literary studies. Scientists included the archival materials from the Polish, German, Swedish and Czech archives into their researches. Historical studies have been devoted to the ancient history of the Ukrainian lands during the Middle Ages, the history of the Cossacks, the Hetmanate, and the period of the Ukrainian Revolution. A number of scientific works were published, that nowadays are an important legacy of the Ukrainian historiography.

Key words: Czechoslovakia, Ukrainian scientific emigration, Ukrainian Historical and Philological Society in Prague, World War II.
\end{abstract}




\title{
ДІЯЛЬНІСТЬ УКРАЇНСЬКОГО ІСТОРИЧНО-ФІЛОЛОГІЧНОГО ТОВАРИСТВА В ПРАЗІ В УМОВАХ ПОЧАТКОВОГО ЕТАПУ ДРУГОЇ СВІТОВОЇ ВІЙНИ (1939 - 1941)
}

\begin{abstract}
Анотація. Мета дослідження - розкрити діяльність Украйнського історично-філологічного товариства в Празі в складних умовах початку Другої світової війни, особливості його функціонування, видання наукових праць та підтримання взаємовідносин з науковими осередками Чехословаччини. Методологія дослідження спирається на використання загальнонаукових (аналіз, синтез, узагальнення) та спечіально-історичних (історико-типологічний, історико-порівняльний) методів, принципах історизму, системності, науковості, верифікаиії, авторської об'єктивності. Завдяки застосуванню історико-типологічного методу автору вдалося з більшою вірогідністю розкрити поставлені мету $i$ завдання дослідження. Наукова новизна полягає у тому, щзо вперше в украӥнській та зарубіжній історіографіїрозкрито діяльність Украӥнського історично-філологічного товариства у Празі в умовах початку Другої світової війни, зокрема, показано видавничу діяльність Товариства в складних політичних та фінансових умовах Висновки. Незважаючи на складні політичні та економічні умови, щуо склалися у Чехословаччині на початку Другої світової війни, Украӥнське історично-філологічне товариство у Празі продовжувало свою діяльність. На його засіданнях розглядалися найрізноманітнімі питання історії та літературознавства. До своїх досліджень вчені залучали архівні матеріали польських, німеиьких, швеиьких та чеських архівів. Історичні дослідження були присвячені питанням давньої історії украӥнських земель, княжсої доби, історії козацтва, гетьманщини та періоду Украӥнської револючії. Було видано цілу низку наукових пращь, які й сьогодні є важливою спадщиною української історіографії.
\end{abstract}

Ключові слова: Чехословаччина, українська наукова еміграція, Українське історичнофілологічне товариство в Празі, Друга світова війна.

The Problem Statement. An important task of a modern historical science is the formation of a historiographic scientific heritage. As it happens under difficult circumstances, some Ukrainian historians were forced to travel outside their own country. Scientists did not abandon researching the past of their nation, under conditions of emigration they continued their research, analyzing materials and documents of the archives of the countries where they went.

After World War I, a part of the Ukrainian scientific and creative intelligentsia emigrated to Czechoslovakia, since conditions in that country were more favourable at that time than in Ukraine under the Soviet Union. In order to work together and fulfill their sincere wishes in the field of research of the history of their homeland, the Ukrainian scientists in Czechoslovakia united and in 1923 they founded a scientific area - the Ukrainian Historical and Philological Society in Prague (hereinafter - the Society).

The activity of the Society was carried out in accordance with the annual plans and every year the number of its members increased. In total, over the entire period of its existence, the Ukrainian Historical and Philological Society numbered about 60 full members (Narizhnyi, 1999, p. 201). According to many scientists, its most active members were D. Antonovych, L. Biletskyi, P. Bohatskyi, D. Doroshenko, I. Ohiienko, S. Siropolko, V. Sichynskyi, V. Shcherbakivskyi and the others. Owing to the experience and a fruitful activity of Dmytro Antonovych, one of the initiators of the formation of the Society, it gained sympathy from the Ukrainian scientific elite and Ukrainian citizens (Narizhnyi, 1999, p. 201). During the academic year, the Society held its public scientific meetings on a weekly basis, at which scientific reports were presented, or papers on various topics were read (Narizhnyi, 1999, p. 202). Owing to the organizational skills and skillful work of D. Antonovych, the Society survived under the most difficult conditions of emigration, although its members were often forced to change places of residence, work, and sometimes professions (Narizhnyi, 1999, p. 204). 
The Analysis of Sources and Recent Researches. The topic of functioning of the Ukrainian Historical and Philological Society in Prague has attracted the attention of many Ukrainian and foreign historians, but their researches concerned, mainly, the interwar period of the Society's activity and was considered mainly through the study of the specific historical figures' activity.

More thoroughly, scientists researched the activities of the Ukrainian Historical and Philological Society in 1923 - 1933 in two directions: as one of the scientific areas created by the Ukrainian expatriates and through the activities of its members -the Ukrainian expatriates.

Thus, the famous Ukrainian scientist S. Vidnianskyi, researching the cultural, educational and scientific activity of the Ukrainian emigrants in Czechoslovakia during 1921 - 1945, shows the general trends of development and formation of academic institutions abroad. His work presents cultural, educational and scientific areas created by the Ukrainian emigrants to continue their scientific activities under more favourable conditions than those established at home. An important aspect of his work is demonstration of the role of the Ukrainian intelligentsia in the development of the Ukrainian people, Czechoslovak society (Vidnianskyi, 1994).

Some aspects of the activity of the Ukrainian Scientific Society in Prague are highlighted in the work of A. Shapoval "Collaboration of Mykhailo Antonovych with the Ukrainian Historical and Philological Society in Prague", where, through a review of documentary essays, the author shows some aspects of the Society's activities. It reveals M. Antonovych's activities and shows the topic of his research (Shapoval, 2012). He shows that, with M. Antonovych's participation in the Society's activities and his donations, a number of publications by famous Ukrainian scientists and publicists were published, including several volumes of "Works" of the scientific society. M. Antonovych's scientific research on the history of the early Cossacks and the history of Ukraine contributed to the introduction of many unpublished materials found in German and Austrian archives into scientific circulation and made a significant contribution to the development of the Ukrainian historical science.

The Ukrainian historian O. Chechyna in her work tried to outline the main activities of the Ukrainian Historical and Philological Society in Prague (1923 - 1945), but, unfortunately, she represented the general trends of functioning of scientific and educational areas of the Ukrainian emigrants in Prague, among them and the Ukrainian Historical and Philological Society. Unfortunately, she failed at illustrating the activities of the Society during 1939 1941 (Chechyna, 2006, pp. 261-266). It is worth mentioning that the author presented the Ukrainian Historical and Philological Society in Prague as a unifying center of the best scientists-emigrants in the Humanities - D. Antonovych, P. Andrievsky, V. Bidnov, D. Doroshenko, V. Shcherbakivsky, S. Smal-Stotsky, O. Kolessa and the others. She concludes that, owing to the activities of the Society at the initial stage of its existence, the European community had the opportunity to learn more about the history, culture, scientific and creative potential of the Ukrainian people.

The purpose of the article is to elucidate the activities of the Ukrainian Historical and Philological Society in Prague under the difficult conditions of the outbreak of World War II, the peculiarities of its functioning, the publication of scientific works and the maintenance of relations with the scientific areas of Czechoslovakia and Germany.

The Statement of the Basic Material. We can see from the research of the Ukrainian scientists that in March 1939, when the German troops occupied the Czech Republic, most of the educational and professional areas of the Ukrainian emigrants in Prague ceased their activity before or at the beginning of World War II. This is evidenced by the research of A. Yavorskyi, who argues that with the outbreak of war in the Czech Republic, the Ukrainian 
Free University was forced to move to Munich (Germany) to continue its activities, the Ukrainian Academy of Economics functioned until 1935, the Ukrainian Law Society, the Ukrainian Pedagogical Society and the Ukrainian Military and Scientific Society were also forced to curtail their activities or move to other countries. The Ukrainian Academic Committee, founded in Prague in 1925 on the initiative of the Ukrainian Historical and Philological Society, ceased its activities in 1932 (Yavorskyi, 2016, pp. 52-59)

The conditions in the capital of the Czech Republic, apparently, were not favourable for the activity of public organizations. The occupying power allowed only a few scientific institutions to function, which, under extremely difficult circumstances, could survive until the end of the war (Levkun, 2012, pp. 121-126).

As the Ukrainian Historical and Philological Society dealt with scientific issues that did not relate to the policies of Czechoslovakia and Germany, it continued its activities at the outbreak and the beginning of World War II. The work of its members was no longer as active as it was during the 20-ies and the beginning of the 30-ies, but it was distinguished by the productivity of its work and by the fact that it was purely scientific - unrelated to politics. Members of the Society assembled to discuss particular scientific issues, to publish their works, and to promote knowledge of the Ukrainian history, language, and culture (Chechyna, 2006, pp. 261-266).

The years of war further complicated the functioning of the Society and the activities of its members. In Czechoslovakia, the population also experienced the Nazi occupation, and the Nazi Gestapo actions were directed against the Czech politicians as well as intelligentsia. Nevertheless, the political concept laid down by the Czechoslovak Government aimed at supporting the scientific and publishing areas that brought together emigrants-experts in political science with different ideological backgrounds continued to be supported by the Society.

Despite the unfavourable conditions of emigration life, as well as the difficult financial situation, the main source of which were membership fees and donations, 65 scientific publications, including 5 volumes: "Proceedings of the Ukrainian Historical and Philological Society in Prague", became a significant asset of the Society (Narizhnyi, 1999, p. 209). At each meeting of the Society, scientific reports were presented on important issues of the Ukrainian culture and history. The topics of the reports at the meetings of the Society were partly initiated by the Society itself, especially concerning the meetings of anniversary and commemorative dates. Periodically, discussions were held in the Society on the birth of the Ukrainian nation. Such discussions, as a rule, caused a widespread publicity in the press and continued for some time outside the Society. During the discussions the Society discussed issues related to Ukrainophilia. This topic always sparked a lively discussion among the members of the Society and the guests invited (Narizhnyi, 1999, p. 210).

The main feature of the reports was their high scientific level, the authors were free to choose topics and methods of historical events coverage, they were able to "... be in positions that stand up to criticism by arguments, but not justified by government orders ...". The publishing house of the Society was not able to satisfy the needs of its members for publication in the desired size, so a considerable part of them was not published (Narizhnyi, 1999, p. 209; Pratsi, 1926, 1939, 1941).

During this period, a number of works by the Ukrainian emigrant scientists were published, including: V. Sitsinskyi "Ukrajinsjka khata v okolycjakh Ljvova" ("Ukrainian House in Lviv Suburbs”);O.Kolessa“Pivdenno-VolynsjkeGhorodyshhetaGhorodysjkirukopysnipam'jatnyky XII-XVI st." ("South Volyn Settlement and City Handwritten Monuments of the XIIth - 
XVIth Centuries"); V. Shcherbakivskyi "Maljovana neolitychna keramika na Poltavshhyni" ("Painted Neolithic Ceramics in Poltava Region"), "Materialy z arkheologhichnykh rozkopiv na Perejaslavshhyni" ("Materials from Archaeological Excavations in Pereyaslav Region"); B. Krupnytskyi "Pylyp Orlyk i Sava Chalyj” ("Pylyp Orlyk and Sava Chalyi”); D. Doroshenko "Stepan Opara, nevdalyj ghetjman Pravoberezhnoji Ukrajiny" ("Stepan Opara, the Unfortunate Hetman of Right-Bank Ukraine"); V. Sadovskyi "Ghospodarsjki poghljady ukrajinsjkogho pomishhyka u pershij polovyni XIX st" ("Economic Views of the Ukrainian Landowner during the first half of the XIXth century"); M. Antonovych "Poghranychnyk Bosyj" ("Border Guards Barefoot"); D. Chyzhevskyi "Ukrajinsjkyj literaturnyj barok" ("Ukrainian Literary Baroque”); S. Narizhnyi "Rozviduvannja moskovsjkykh poslanciv na Ukrajini”" "Investigation of Moscow Envoys in Ukraine") and many others. The vast majority of papers presented at the Society meetings and articles by the Ukrainian scientists were published in three volumes of future fivevolume work during 1926 - 1941 (Richne spravozdannia, 1941, p. 8).

In March 1941, at the regular meeting of the Ukrainian Historical and Philological Society in Prague, M. Antonovych presented an essay on "Bernat Pretwicz - Headmaster at the Bar" and V. Shcherbakivsky presented the concept of Hrushevsky on the origin of the Ukrainian nation according to the paleontology researches. The Annual Report on the years of $1940-$ 1941 stated that these works were included into the third volume of the Proceedings of the Ukrainian Historical and Philological Society in Prague in 1941 (CDAGO of Ukraine, f. 269, op. 1 , ref. 416 , fol. 177,180 ).

In addition to organizing scientific meetings, the Ukrainian Historical and Philological Society also performed scientific, organizational and representative functions, taking an active part in organizing and operating scientific forums of various levels - Ukrainian, Slavic, European and world, in various anniversary and celebrating meetings. The following congresses include: the Slavic geographers and ethnographers congresses in Prague, the Second International Linguistic Congress.

After a short break in 1938 - 1939, the Society resumed its activity by holding an average of 20 meetings annually. Thus, in 1939 - 1941 the Ukrainian Historical and Philological Society held 38 scientific meetings, at which 48 reports were discussed (Narizhnyi, 1942, p. 199). All these aspects gave reason to S. Narizhnyi to claim that the number and regularity of the scientific meetings and read reports and abstracts of the Society had no equal among such Ukrainian scientific and educational institutions, both in Ukraine and abroad. It is worth noting that most of the 611 scientific reports and abstracts were original scientific studies. Thus, in particular, the little-studied questions on the art of Ukraine D. Antonovych, V. Sichynskyi covered in their scientific essays (Narizhnyi, 1942, pp. 200-201).

We also learn about the topics of the meetings and the nature of the discussions from the annual reports of the Ukrainian Historical and Philological Society in Prague from May 31, 1940 to May 30, 1941 (Richne spravozdannia, 1941, p. 8).

In 1940 the following members were admitted to the Society: Dr. Mykola Hnatyshak, Dr. Mykola Andrusiak, Dr. Volodymyr Birchan, Professor, Dr. Ivan Zilinsky, Professor, Dr. Myron Kordub, Professor, Dr. Vladimir Kubievich, Professor, Dr. Zenon, Kuzel Lepky, Dr. Eugene Yuri Pelensky, Professor, Dr. Ivan Rakovsky and Associate Professor Yaroslav Rudnitsky and the others. The full members of the Society were: a lecturer at the German University in Munich, and Professor Kornilo Zaklinsky, former director of the State High School in Berehove. Acceptance of all mentioned members was organized according recommendations by of the Society members by a secret ballot (Richne spravozdannia, 1941, p. 9). 
Thus, at the beginning of 1941, the membership of the Society was enlarged by eleven members, and in total 65 members were employed in the Society, 54 of them were full members and 11 members - employees. Professor D. Antonovych continued to be the Head, Professor D. Doroshenko was the Deputy, and Professor S. P. Narizhnyi was the Secretary.

The main activity of the Society, as can be seen from the reports for the years 1940 - 1941 were meetings and making important decisions on them and publishing scientific and popular science literature.

Scientific reports and discussions were constantly made at the meetings of the Society. For instance, at one of the meetings in 1940, Dr. M. Andrusiak and Professor K. Zaklynskyi made speeches coming from Berlin. Dr. M. Antonovych's report on Pretwicz was also presented by the visiting members of the Society, and Professor B. Krupnytsky's research "From the History of the Right Bank during 1683 - 1688" was summarized at two meetings. In addition, the full members of the Society read their reports: P. O. Bohatskyi, S. P. Narizhnyi, I. Pankevych, V. V. Sadovskyi, S. O. Siropolko. A total of 33 reports were read in 1940 and early 1941 in the Society. Accordingly, the total number of reports reached 662 during the years of the Society activities (Richne spravozdannia, 1941, pp. 9-10).

If we analyze the reports presented at the meetings of the Society, it must be said that in content they were from different areas of social sciences, in particular, there were studies in history, ethnology, law, art, education, philology and the others. A considerable number of reports during the 1940 - 1941 were devoted to the research of the German-Ukrainian relations, in particular, the reports of Professor A. Yakovlev in the field of law, Professor D. Doroshenko about literary monuments, Professor S. Siropolk about the German Schweipolt Fiol, the first printer of the Slavic Cyrillic books. Professor S. Siropolk's second report was devoted to Chernihiv College. In the same way, Professor V. Shcherbakivskyi's reports on the social and religious type of the Ukrainian, as well as his consideration of the question of the social structure of the Pro-Ukrainian people, became sections of general works. The reports of the Head of the Society - D. Antonovych were devoted to: Ukrainian architecture in the Governor General, Shevchenko studies, the history of the theater and other issues of the Ukrainian history.

From the reports of Professor D. Antonovych and Professor S. Narizhnyi we learn about the activities of the Historical and Philological Society in Kharkiv and Odessa Society of History and Antiquity, so we can judge the organization and activity of scientific and historical work in Ukraine under the conditions of the beginning of World War II and the Soviet regime on Western Ukrainian lands.

In addition to the issues of the Ukrainian history, the problems of the city and village in Ukraine in the historical and economic aspect were also considered (Professor V. Sadovskyi). The questions of the Semyhorod Ukrainians were devoted to the reports of Ivan Pankevych. The bibliographical reports on the wealth of the Ukrainians were important in the library of the Czech National Museum of K. Zaklynskyi and P. Bohatskyi. They emphasized that not only the latest Ukrainian editions, but also many works from Ukrainian of the last century are presented in the library, most of them with autographs by O. Bodianskyi, M. Maksymovych, V. Bilozerskyi, M. Sumpov and other well-known Ukrainian researchers and publicists.

Issues of the Ukrainian history were presented at the meetings of the Society, which, according to the majority of its members, required deep research and reflection. Such questions were suggested to be explored by young scientists, who were just beginning to prove themselves in science. 
P. Bogatskyi's researches on the collection of works that compiled Shevchenko's bibliography from 1930 to 1940 were important. Through this extensive work, he continued his previous research on the topic, some of which have already been presented at Society meetings in recent years.

On March 11, 1941 the meeting of the Society was held dedicated to the works that covered the activities of Taras Shevchenko and his personality. The reports were devoted to the work of Taras Shevchenko as an artist. Summarizing the activities of the Society in the field of Shevchenko studies, it was noted that during 26 traditional meetings of the Society, 48 reports were presented, which presented to the scientific community thorough research and interpretations of Shevchenko's creative heritage.

The publishing activity of the Society is also significant, so the number of all publications as of March 1941 reached 56 works. The result of the publishing activity of the Society in 1940 was the appearance of the third volume of works of several separate publications.

It should be noted that for the development of its own publishing activity the Society never had the necessary funds. Despite this, the first volume was published in 1926, and then only ten years later they began to publish the second volume of this edition.

The second volume was scheduled for publication in 1937, but lacking the same funds, it was published as early as 1939 under other political circumstances and with some debt obligations.

The publication of the third volume was supported by members of the Society, who were in Germany at the time, in particular Professor D. Antonovych and Professor D. Chyzhevskyi. These activists rightly pointed at the particular need at this time to uphold the tradition of scientific Ukrainian publications. They offered their own funds to publish this volume of the Society's Works. This volume became especially valuable. It was completed and published in March 1941. It included the works by well-known Ukrainian scientists: Mykhailo Antonovych with his work "Border Guards Barefoot" (Pratsi, 1941, p. 11), Borys Krupnytskyi with his work "From the Life of the First Ukrainian Emigration" (Central State Archives of Public Associations of Ukraine (hereinafter - CSAGOU), f. 269, op. 1, c. 416, fol. 179-179), Vadym Shcherbakivskyi's "Concept of M. Hrushevsky about the Origin of the Ukrainian People in the Light of Paleontology", Dmytro Chyzhevskyi "Ukrainian Literary Baroque", Ivan Pankevych "Literary Biedermeier in Galician-Ukrainian Writing" and Symon Narizhnyi "Investigation of Moscow Envoys in Ukraine: during the second half of the XVIIth Century."

Each of these works, in addition, publishes as a separate edition of the Society. The circulation of this volume was 300 copies, and the individual prints of it from 50 to 80 copies of each. In general, if we outline the topics of the research and their presentation at the Society's meetings during 1941, we can say that during these six and a half years, most issues of the Ukrainian history and culture were addressed.

Despite the difficult conditions of the war, the Society met and worked according to the plan. Traditionally, each meeting lasted about two hours, and the programme of the meeting consisted of two reports and a discussion, but subsequent meetings, given the political complications, had only one report and discussion.

In terms of content, there were most reports on history, much less historical literary and archeological issues that covered other areas of the Society. Thus, in 1940, Professor V. Sadovskyi made reports as a summary to his historical and economic essays from the previous course on the topic "Economic Views of the Ukrainian Landowner of the First Half of the XIXth Century". Also F. Slusarenko's report “Athena and the Bosporus" was interdisciplinary and by this work he completed a number of his analytical works on selected Greek speeches from the 4th century BC. 
Archeological research reports "Abridged Funerals of the Princes of the Czech Republic" were presented by Professor, Dr. I. Borkovskyi, who was prepared for a speech at the Oslo International Science Congress. Also one of his works was "New Findings of Bronze Treasures from the Subcarpathian".

Dr. O. Kandyba made a great report on the chronology of the European Neolithic, illustrating a comparative table.

An important area of work of the Society was the reports made at international conferences and congresses. Unfortunately, however, with the outbreak of the war, the scientific community had been gathering less and less to discuss important scientific issues.

In 1941 the activities of the Society were marked by a quite noticeable cooperation of foreign members. Associate Professor Dr. B. Krupnytskyi spoke at the Society's discussion about the political plans of Hetman Mazepa in connection with Charles XII's plans before the Swedes went to Ukraine and about P. Orlyk's unpublished correspondence. B. Krupnytskyi noted that archival materials and documents from the Stockholm State Archives were based on the materials prepared for the report. These materials also helped him to understand the relationship between Pylyp Orlyk and Sava Chalyi.

Working with the materials of the Danzig archives, Dr. M. Antonovych explored some moments in the history of the Ukrainian Cossacks during the 1930-ies. This is, in particular, his work "The Cossack during the 1930-ies".

V. Prokopovych's reports on the history of Ukrainian sphragistics, in particular, about the Malorosiyska Press and Professor D. Doroshenko's report on Stepan Opara, in which the author used unpublished archival materials from Warsaw archives, were interesting.

The Conclusions. Nowadays, it must be admitted that, despite the difficult political and economic conditions, the Ukrainian Historical and Philological Society continued to function. At the meetings of the Society a variety of issues of history and literary studies were discussed. Scientists included archival materials from the Polish, German, Swedish and Czech archives into their research. Historical studies were devoted to the ancient history of the Ukrainian lands, the princely era, the history of the Cossacks, the Hetmanate, and the period of the Ukrainian Revolution.

Among the valuable achievements of the Ukrainian Historical and Philological Society in Prague was its scientific and publishing activity, which was greatly complicated by the lack of state funding, which is why active work was started to set up its own publishing house to publish the scientific works of its members. The Society was able to publish as of 194165 scientific publications, and for the whole period of its existence $(1923-1945)-67$. Among them, five volumes of the "Proceedings of the Ukrainian Historical and Philological Society in Prague" $(1926,1939,1941,1942,1944)$. In addition, members of the Society used every opportunity to publish their research in other journals of Czechoslovakia and beyond.

In general, the Society ceased its activities because of the Soviet occupation of Prague and moved to Munich, where in 1945 only for a short time under the chairmanship of V. Scherbakivskyi resumed its activities.

Acknowledgments. The author express gratitude to the International Visegrad Foundation for their help and help in collecting material for a scientific article.

Funding. The author received no financial support for the research, authorship, and/or publication of this article.

\section{BIBLIOGRAPHY}

Chechyna, O. D. (2006). Osnovni napriamky diialnosti ukrainskoho istoryko-filolohichnoho tovarystva v Prazi (1923 - 1945 rr.) [The main Activities of the Ukrainian Historical and Philological 
Society in Prague (1923 - 1945 rr.)]. Naukovi zapysky Vinnytskoho derzhavnoho pedahohichnoho universytetu imeni Mykhaila Kotsiubynskoho. Seriia: Istoriia, 11, 261-266. [in Ukrainian]

Levkun, Ya. (2012). Ivan Borkovskyi ta ukrainskyi naukovyi svit Prahy [Ivan Borkovsky and the Ukrainian Scientific World of Prague]. Skhid, 2, 121-126. [in Ukrainian]

Narizhnyi, S. (1942). Ukrainska emigratsiia: kulturna pratsia ukrainskoi emihratsii mizh dvoma svitovymy viinamy [Ukrainian Emigration: Cultural Work of Ukrainian Emigration between the Two World Wars]. Part 1. Praha, 1942. 372 p. URL: http://diasporiana.org.ua/istoriya/2648-narizhniy-sukrayinska-emigratsiya-kulturna-pratsya-ukrayinskoyi-emigratsiyi-mizh-dvoma-svitovimi-viynamich-1/ [in Ukrainian]

Narizhnyi, S. (1999). Ukrainske istoryko-filolohichne tovarystvo v Prazi v 1925 - 1938 rr. [Ukrainian Historical and Philological Society in Prague in 1925 - 1938]. Khronika - 2000 [Chronicle - 2000]. Ukrainskyi kulturolohichnyi almanakh, 2 ("Ukraina-Chekhiia"), 173-209. [in Ukrainian]

Pelenska, O. (2019). Ukraina poza Ukrainoiu. Entsyklopedychnyi slovnyk mystetskoho, kulturnoho i hromadskoho zhyttia ukrainskoi emihratsii v mizhvoienii Chekhoslovachchyni (1919-1939) [Ukraine outside Ukraine. Encyclopedic Dictionary of Art, Cultural and Public Life in Ukrainian Emigration in Interwar Czechoslovakia (1919 - 1939)]. Praha, 331 p. [in Ukrainian]

Pratsi. (1939). Pratsi Ukrainskoho istorychno-filolohichnoho tovarystva u Prazi [Proceedings of the Ukrainian Historical and Philological Society in Prague]. Vol. II. Praha. 240 p. URL: http://diasporiana.org.ua/wp-content/uploads/books/12069/file.pdf [in Ukrainian]

Pratsi. (1941). Pratsi Ukrainskoho istorychno-filolohichnoho tovarystva u Prazi [Proceedings of the Ukrainian Historical and Philological Society in Prague]. Vol. 3. Praha: Vydannia Ukrainskoho Istorychno-Filolohichnoho Tovarystva v Prazi, 140 p. [in Ukrainian]

Richne spravozdannia. (1941). Richne spravozdannia Ukrainskoho istoryko-filolohichnoho Tovarystva u Prazi (1936 - 1937) [Annual Report of the Ukrainian Historical and Philological Society in Prague (1936 - 1937)]. Praha. 16 p. [in Ukrainian]

Richne spravozdannia. (1941). Richne spravozdannia Ukrainskoho istoryko-filolohichnoho Tovarystva u Prazi (1940 - 1941) [Annual Report of the Ukrainian Historical and Philological Society in Prague (1940 - 1941)]. Praha. 16 p. [in Ukrainian]

Shapoval, A. I. (2012). Spivpratsia Mykhaila Antonovycha z Ukrainskym istorychno-filolohichnym tovarystvom u Prazi [Cooperation of Mykhailo Antonovych with the Ukrainian Historical and Philological Society in Prague]. Arkhivy Ukrainy, 4 (280), 88-99. URL: http://irbis-nbuv.gov.ua/ everlib/item/er-0000000224 [in Ukrainian]

Tsentralnyi dkerzhavnyi arkhiv hromadskykh obiednan Ukrainy [Central State Archive of Public Associations of Ukraine - CSAPAU]

Ulianovska, S. \& Ulianovskyi, V. (1993). Ukrainska naukova i kulturnytska emihratsiia u Chekho-Slovachchyni mizh dvoma svitovymy viinamy [Ukrainian Scientific and Cultural Emigration in Czechoslovakia between the Two World Wars]. URL: http://litopys.org.ua/cultur/cult25.htm [in Ukrainian]

Vidnianskyi, S. V. (1994). Kulturno-osvitnia i naukova diialnist ukrainskoi emihratsii v ChekhoSlovachchyni: Ukrainskyi vilnyi universytet (1921 - 1945 rr.) [Cultural, Educational and Scientific Activities of the Ukrainian Emigration in Czechoslovakia: Ukrainian Free University (1921 - 1945)]. URL: http://history.org.ua/JournALL/Preprint/1994/1.pdf [in Ukrainian]

Yavorskyi, A. (2016). Profesiino-naukovi orhanizatsii ukrainskoi emihratsii u Chekhoslovachchyni v $20-30$-kh rr. XX st. [Professional and Scientific Organizations of Ukrainian Emigration in Czechoslovakia during the 20 - 30-ies of the XXth century]. Evropský filozofický a historický diskurz. Praha: Berostav druћstvo, Svazek 2 (3), 52-59. [in Ukrainian]

The article was received on January 17, 2020. Article recommended for publishing 26/11/2020. 